\title{
IMPLIKASI PEMBATASAN YURIDIS PEMBUBARAN PARTAI POLITIK TERHADAP PRINSIP DEMOKRASI
}

\author{
Josef M. Monteiro ${ }^{1}$
}

\begin{abstract}
Abstrak
The dismissal of political party still rises polemic due to its existence in a state having democratic political system which is assumed as a "condition sine quanon". Nevertheless, based on judicial point of view a political party can be dismissed if its ideology is opposed to state ideology and abusing the law. The dismissal of political party by the constitution supreme court could only be carried out based on judicial reasons such as trespassing forbidden rules as confirmed in the article 40 Act No.2 Of The Year 2008 Concerning Political Party. However, its implementation still rises uncertainty democracy principle due to the existence of judicial limitations related to the article 68 point one (1) and point two (2) Act No.24 Of The Year 2003 Concerning The Constitution Supreme Court justified as to rise obscurity. Therefore the step to be done is to revise the article 68 point one (1) which is considered not democratic and hindering the public to claim a particular political party trespassing, and the sentence formulation in article 68 point two (2) is provided broad or extensive interpretation.It is hoped that in the state of law as Indonesia, might create the certainty of law and the realization of the principle of equality before the law.
\end{abstract}

Katä Kunci: partai politik, demokrasi, kekaburan, revisi

\section{Pendahuluan}

Dewasa ini banyak negara di dunia telah mengakomodasi partai politik di dalam sistem politik yang demokratis. Hal ini juga dilakukan oleh negara Republik Indonesia yang dalam sistem demokrasi konstitusional telah mengakomodasi partai politik dalam rangka mewujudkan kedaulatan rakyat. Perwujudan kedaulatan rakyat ini kemudian dilakukan dengan penyelenggaraan pemilihan umum. Dalam konteks pemilihan umum partaipartai politik berperan terutama menjadi kontestan pemilu.

${ }^{1}$ Dosen Tetap Fakultas Hukum Universitas Nusa Cendana Kupang, NTT. Alamat kontak: mario_jose98@yahoo.com. 
Oleh karena itu partai politik perlu diberi ruang terbuka dan kebebasan sehingga dapat menyerab aspirasi rakyat. Penyerapan aspirasi rakyat tidaklah mungkin terwujud jika ada pembatasan terhadap iklim keterbukaan dan kebebasan. Jikalau terdapat adanya pembatasan itu hanyalah disebabkan karena, pertama, sifat pemerintahan yang otoriter, dan kedua, partai-partai politik yang terlalu banyak sehingga tidak bisa dihindarkan adanya pengetatan terhadap jumlah partai politik. Hal ini berbeda jikalau terdapat adanya pembubaran partai politik, yang sudah barang tentu sangat bertentangan dengan nilai-nilai demokrasi dan hak asasi manusia.

Namun demikian dalam sejarah kepartaian di Indonesia telah terjadi pembatasan bahkan pembubaran partai politik yang disebabkan berbagai pertimbangan antara lain ideologinya bertentangan dengan ideologi negara (Pancasila) dan kebijakan pemerintah. Kita bisa melihat pada masa Orde Lama, peran yang dimainkan Partai Masyumi dan Partai Sosialis Indonesia (PSI) yang menurut Soekarno begitu kopeg terhadap kebijakan demokrasi Demokrasi Terpimpin. Akibat dari kedua partai politik tersebut tidak mendukung kebijakan sentralistis Pemerintahan Soekarno ini, maka kedua partai politik tersebut pada akhirnya dibubarkan oleh sang penguasa. Sedangkan partai-partai politik yang tetap hidup merupakan partai-partai politik pendukung kebijakan pemerintah sehingga hanya bagian dari interest group dan preference groups.

Pembubaran partai politik terjadi pula pada awal masa Orde Baru dengan dibubarkannya Partai Komunis Indonesia (PKI) yang dinilai bertentangan dengan ideologi Pancasila. Selain itu pada fase Orde Baru terdapat pembatasan jumlah partai politik yang mulai dilakukan sejak Januari 1973, dengan mengebiri sistem multipartai melalui kebijakan fusi partaipartai politik sejenis ke dalam beberapa partai politik. Partai Islam (baik itu modernis ataupun tradisionalis), seperti Nahdlatul Ulama (NU), Partai Muslimin Indonesia (Parmusi), Partai Persatuan Tarbyiah Indonesia (Perti), dan Partai Serikat Islam Indonesia (PSSI) digabungkan ke dalam Partai Persatuan Pembangunan (PPP).

Sedangkan partai-partai politik yang mengusung ideologi nasionalis dan non-Islam, yakni Partai Nasional Indonesia (PNI), Ikatan Pendukung Kemerdekaan Indoneisa (IPKI), Partai Murba, Partai Katolik, dan Partai Kristen Indonesia (Parkindo), digabungkan ke dalam Partai Demokrasi Indonesia (PDI). ${ }^{2}$ Lain halnya dengan Golongan Karya (Golkar) tetap dibiarkan sebagai partai politik semu yang mengandalkan massa mengambang (floating mass). Golkar bernaung dalam Sekretariat Bersama

${ }^{2}$ R. William Liddle, "Pemilu-Pemilu Orde Baru: Pasang Surut Kekuasaan Politik", (Jakarta: LP3ES, 1994), hal. 49. 
Golongan Karya (Sekber Golkar), yang merupakan gabungan beberapa organisasi massa dan organisasi fungsional yang tidak terwakili oleh dua parpol lainnya, seperti Kosgoro, MKGR, SOKSI, Satkar Ulama, dan Korpri.

Sejak reformasi fenomena sistem multipartai dimulai lagi dengan beragam bentuk ideologi baik itu berbentuk ideologi personal, kelompok atau organisasional. Namun demikian upaya untuk membatasi jumlah partai politik tetap dilakukan antara lain dengan ketentuan electoral threshold dan hal ini dilakukan sejak pemilihan umum 2004. Adapun ketentuan electoral threshold yaitu batas perolehan suara bagi partai politik untuk bisa ikut pemilihan umum selanjutnya. Dalam perkembangan selanjutnya yakni pada pemilihan umum 2009, selain ditetapkan ketentuan electoral threshold juga diberlakukan ketentuan parliamentary threshold yakni batas peroleh kursi bagi partai politik untuk bisa mengirimkan wakil di DPR RI. Gagasan parliamentary threshold digunakan sebagai upaya untuk mengurangi fragmentasi politik di parlemen sehingga menyerdehanakan sistem kepartaian.

Meskipun demikian dapatlah dikatakan bahwa dalam setiap penyelenggaran pemilihan umum $(1999,2004$, dan 2009) tidak terdapat adanya pembubaran partai politik. Akan tetapi tidaklah berarti dalam perkembangan selanjutnya partai-partai politik tidak dapat dibubarkan. Apabila terdapat partai politik tertentu yang terbukti melanggar hukum yakni salah satunya melanggar Undang-Undang Nomor 2 Tahun 2008 Tentang Partai Politik, maka sudah barang tentu Mahkamah Konstitusi berwenang membubarkannya. Mekanisme pembubaran partai politik diatur secara tegas dalam Pasal 24C ayat (1) UUD 1945 yakni "Mahkamah Konstitusi mengadili pada tingkat pertama dan terakhir yang putusannya bersifat final untuk memutus pembubaran partai politik..."

Namun demikian untuk membubarkan suatu partai politik tidaklah mudah karena terdapat adanya pembatasan-pembatasan yuridis. Seperti salah satunya adalah terkait dengan pihak yang dapat memohonkan pembubaran partai politik sebagaimana yang diatur dalam Undang-Undang Nomor 2 Tahun 2008 Tentang Partai Politik. Berdasarkan undang-undang tersebut dinyatakan bahwa pihak yang dapat memohonkan pembubaran partai politik adalah hanya Pemerintah (Pusat).

Oleh karena itu masyarakat tidak dapat mengajukan permohonan kepada Mahkamah Konstitusi untuk membubarkan partai politik yang melanggar hukum. Keadaan ini semakin sulit apabila partai politik yang melanggar hukum justru partai pemerintah, apakah pemerintah mau mengajukan permohonan kepada Mahkamah Konstitusi untuk memeriksa dan membubarkan parpolnya yang terbukti melanggar hukum. Berdasarkan hal tersebut maka tulisan ini mencoba menganalisis bagaimanakah implikasi 
pembatasan yuridis pembubaran partai politik terhadap prinsip demokrasi di Indonesia.

\section{Partai Politik dan Mahkamah Konstitusi Dalam Politik yang Demokratis}

\section{A. Keberadaan Partai Politik Dalam Politik Demokratis}

Partai politik merupakan salah satu pilar dalam sistem politik yang demokratis sehingga keberadaan partai politik dijadikan sarana untuk menghimpun ekspresi, ide, pikiran, pandangan, dan keyakinan masyarakat serta dijadikan juga sarana untuk meraih kekuasaan terutama jabatan legislatif dan eksekutif. Selain itu partai politik memiliki kedudukan (status) dan peranan (role) yang sentral untuk menghubungkan antara pemerintah negara (the state) dengan warga negaranya (the citizens). Dengan demikian menurut Schattscheider, ${ }^{3}$ "Political parties created democracy", partai politiklah yang membentuk demokrasi, dan bukan sebaliknya.

Berkaitan dengan hal tersebut maka sejak Indonesia merdeka, keberadaan partai politik di Indonesia telah mendapat legitimasi dan bertumbuh melalui sejumlah fase, yakni fase pergerakan kemerdekaan, fase demokrasi liberal, fase demokrasi terpimpin, fase Orde Baru, dan fase reformasi. Keberadaan partai politik ini tidak terlepas dari prinsipprinsip kemerdekaan berpendapat (freedom of expression), berorganisasi (freedom of association), dan berkumpul (freedom of assembly). Ketiga prinsip tersebut diakui dan dijamin oleh UndangUndang Dasar Negara Republik Indonesia Tahun 1945. Pada Pasal $28 \mathrm{E}$ ayat (3) ditegaskan bahwa "setiap orang berhak atas kebebasan berserikat, berkumpul, dan mengeluarkan pendapat". Selanjutnya untuk mengatur partai politik, dewasa ini pemerintah menetapkan peraturan perundang-undangan partai politik yakni Undang-Undang Nomor 2 Tahun 2008 Tentang Partai Politik.

Pada Pasal 1 angka 1 Undang-Undang Nomor 2 Tahun 2008 Tentang Partai Politik dinyatakan bahwa partai politik adalah organisasi yang bersifat nasional dan dibentuk oleh sekelompok warga negara Indonesia secara sukarela atas dasar kesamaan kehendak dan cita-cita untuk memperjuangkan dan membela kepentingan politik

3 Schttscheider dalam Jimly Asshiddiqie, "Pokok-Pokok Hukum Tata Negara Indonesia", (Jakarta: PT. Bhuana Ilmu Populer, 2007), hal. 710. 
anggota, masyarakat, bangsa dan negara, serta memelihara keutuhan Negara Kesatuan Republik Indonesia berdasarkan Pancasila dan Undang-Undang Dasar Negara Republik Indonesia Tahun 1945. Ketentuan ini sejalan dengan yang dikemukakan oleh A.Appadorai: ${ }^{4}$

A political is a more or less organized group of citizenz who act together as a political unit, have distinctive aims and opinions on the leading political question of controversy in the State, and who, by acting together as a political unit, seek to obtain control of the Government. It is based on two fundamental of human nature: men differ in their opinions, and are gregarious; they try to achieve by combination what they cannot achieve individually.

Oleh karena itu dalam rangka memperkukuh pelaksanaan prinsip kemerdekaan berpendapat (freedom of expression), berorganisasi (freedom of association), dan berkumpul (freedom of assembly) tersebut, maka partai politik menyelenggarakan beberapa fungsi, yang menurut Miriam Budiardjo meliputi: (i) sarana komunikasi politik, (ii) sosialisasi politik (political socialization), (iii) sarana rekruitmen politik (polical recruitment), dan (iv) pengatur konflik (conflict management). ${ }^{5}$ Sedangkan dalam istilah Yves Meny dan Andrew Knapp, fungsi partai politik mencakup: (i) mobilisasi dan integrasi, (ii) sarana pembentukan pengaruh terhadap perilaku memilih (votting patterns), (iii) sarana rekruietmen politik, dan (iv) sarana elaborasi pilihan-pilihan kebijakan. ${ }^{6}$ Tak jauh berbeda dengan kedua pendapat tersebut, Sigmund Neumann mengemukakan pula fungsi partai politik, yakni: (i) mengatur kehendak umum yang kacau, (ii) mendidik warga negara untuk bertanggung jawab secara politik, (iii) penghubung antara pemerintah dan pendapat umum, dan (iv) menyeleksi para pemimpin. $^{7}$

${ }^{4}$ A. Appadorai, "The Substance of Politics", (New Delhi: Oxford University Press, 2005), hal. 537-538. $163-164$.

${ }^{5}$ Miriam Budiardjo, "Dasar-Dasar Ilmu Politik", (Jakarta: PT.Gramedia, 1977), hal.

${ }^{6}$ Yves Meny and Andrew Knapp, "Government and politics in Western Europe: Britain, France, Italy, Germany", dalam Jimly Asshiddiqie, "Pokok-Pokok Hukum Tata Negara Indonesia", (Jakarta: PT.Bhuana Ilmu Populer, 2007), hal. 717. 
Selanjutnya Jimly Asshiddiqie menjelaskan fungsi-fungsi partai politik sebagai berikut ${ }^{8}$, fungsi pertama, sebagai sarana komunikasi politik, partai politik berperan sangat penting dalam upaya mengartikulasi kepentingan (interest articulation) atau political interest yang terdapat atau terkadang yang tersembunyi dalam masyarakat. Berbagai kepentingan itu diserap sebaik-baiknya oleh partai politik menjadi ide, visi dan kebijakan partai politik yang bersangkutan. Setelah itu, ide dan kebijakan atau aspirasi kebijakan itu diadvokasikan sehingga diharapkan dapat mempengaruhi atau bahkan menjadi materi kebijakan kenegaraan yang resmi.

Fungsi kedua, terkait dengan komunikasi politik itu, partai politik juga berperan penting dalam melakukan sosialisasi politik (political socialization). Ide, visi, dan kebijakan strategis yang menjadi pilihan partai politik dimasyarakatkan kepada konstituen untuk mendapatkan umpan balik (feedback) berupa dukungan dari masyarakat luas. Terkait dengan sosialisasi politik ini, partai politik juga sangat berperan penting dalam rangka pendidikan politik. Partai politiklah yang menjadi struktur antara (intermediate structur) yang harus memainkan peran dalam membumikan cita-cita kenegaraan dalam kesadaran kolektif masyarakat.

Selain kedua fungsi parta politik tersebut, fungsi ketiga, partai politik berfungsi juga sebagai sarana rekruitmen politik. Pembentukan partai politik memang dimaksudkan untuk menjadi kendaraan yangn sah untuk menyeleksi kader-kader pemimpin negara pada jenjangjenjang dan posisi-posisi tertentu. Kader-kader itu ada yang dipilih secara langsung oleh rakyat, ada pula yang dipilih melalui cara yang tidak langsung, seperti oleh Dewan Perwakilan Rakyat. Tentu tidak semua jabatan dapat diisi oleh peranan partai politik sebagai sarana rekruitmen politik. Jabatan-jabatan profesional di bidang kepegawainegerian, dan lain-lain yang tidak bersifat politik tentunya tidak boleh melibatkan partai politik. Partai politik hanya boleh terlibat dalam pengisian jabatan-jabatan yang bersifat politik, oleh karena itu pengangkatannya juga membutuhkan prosedur politik.

Fungsi keempat partai politik adalah pengatur dan pengelola konflik yang terjadi dalam masyarakat (conflict management). Hal ini

${ }^{7}$ Sigmund Neumann, Ke Arah Suatu Studi Perbandingan Partai Politik, dalam Miriam Budiardjo, "Partisipasi dan Partai politik: Sebuah Bunga Rampai", (Jakarta: PT. Gramedia, 1982), hal. 63-64.

${ }^{8}$ Jimly Asshiddiqie, Op Cit, hal. 718-720. 
berkaitan dengan nilai-nilai dan kepentingan-kepentingan yang tumbuh dalam masyarakat sangat beranekaragam, rumit, dan cenderung saling bersaingan dan bertabrakan satu sama lain. Jika partai politiknya banyak, berbagai kepentingan yang beranekaragam itu dapat disalurkan melalui polarisasi partai-partai politik yang menawarkan ideologi, program, dan alternatif kebijakan yang berbeda satu sama lain. Dengan kata lain sebagai pengatur atau pengelola konflik partai politik berperan sebagai sarana agregasi (aggregation of interests) yang menyalurkan ragam kepentingan yang berbeda-beda itu melalui saluran kelembagaan partai politik.

Dalam Undang-Undang Nomor 2 Tahun 2008 Tentang Partai Politik pada Bab V disebutkan tujuan dan fungsi didirikannya suatu partai politik. Pada Pasal 10 ayat (1) disebutkan bahwa tujuan umum partai politik adalah:

a. Mewujudkan cita-cita nasional bangsa Indonesia sebagaimana dimaksud dalam Pembukaan Undang-Undang Dasar Negara Republik Indonesia Tahun 1945.

b. Menjaga dan memelihara keutuhan Negara Kesatuan Republik Indonesia.

c. Mengembangkan kehidupan demokrasi berdasarkan Pancasila dengan menjunjung tinggi kedaulatan rakyat dalam Negara Kesatuan Republik Indonesia

d. Mewujudkan kesejahteraan bagi seluruh rakyat Indonesia.

Sedangkan ayat (2) menyebutkan tujuan khusus partai politik adalah:

a. Meningkatkan partisipasi politik anggota dan masyarakat dalam rangka penyelenggaraan kegiatan politik dan pemerintahan

b. Memperjuangkan cita-cita Partai politik dalam kehidupan bermasyarakat, berbangsa, dan bernegara.

c. Membangun etika dan budaya politik dalam kehidupan bermasyarakat, berbangsa, dan bernegara.

Selanjutnya pada Pasal 11 disebutkan fungsi partai politik adalah:

a. Pendidikan politik bagi anggota dan masyarakat luas agar menjadi warga negara Indonesia yang sadar akan hak dan kewajibannya dalam kehidupan bermasyarakat, berbangsa, dan bernegara.

b. Penciptaan iklim yang kondusif bagi persatuan dan kesatuan bangsa Indonesia untuk kesejahteraan masyarakat. 
c. Penyerap, penghimpun, dan penyalur aspirasi politik masyarakat dalam merumuskan dan menetapkan kebijakan negara.

d. Partisipasi politik warga negara Indonesia.

e. Rekrutmen politik dalam proses pengisian jabatan politik melalui mekanisme demokrasi dengan memperhatikan kesetaraan dan keadilan gender.

\section{B. Fungsi Mahkamah Konstitusi Dalam Politik Demokratis}

Dalam rangka menciptakan sistem politik yang demokratis di Negara Kesatuan Republik Indonesia, maka perlu dibentuk institusi kehakiman yang dapat menegakan hukum dan keadilan berdasarkan Pancasila dan Undang-Undang Dasar Negara Republik Indonesia Tahun 1945. Keberadaan institusi kehakiman dimaksudkan agar kekuasaan negara dapat dibatasi karena jika kekuasaan negara tidak dibatasi maka kekuasaan negara menjadi absolut. Hal ini senada dengan ungkapan Lord Acton, bahwa kekuasaan itu cenderung korup (power tends to corrupt) dan kekuasaan mutlak menjadi korup secara mutlak pula.

Oleh karena itu dalam Pasal 24 Undang-Undang Dasar Negara Republik Indonesia diatur mengenai kekuasaan kehakiman yakni:

(1) Kekuasaan kehakiman merupakan kekuasaan yang merdeka untuk menyelenggarakan peradilan guna menegakan hukum dan keadilan.

(2) Kekuasaan kehakiman dilakukan oleh sebuah Mahkamah Agung dan badan peradilan yang berada dibawahnya dalam lingkungan peradilan umum, lingkungan peradilan agama, lingkungan peradilan militer, lingkungan peradilan tata usaha negara, dan oleh sebuah Mahkamah Konstitusi.

(3) Badan-badan lain yang fungsinya berkaitan dengan kekuasaan kehakiman diatur dalam undang-undang.

Dalam konteks pembentukan Mahkamah Konstitusi dapatlah dikatakan bahwa pada prinsipnya pembentukan institusi tersebut dimaksudkan untuk menjaga dan memperkuat dasar-dasar konstitusionalisme sebuah perundang-undangan, artinya Mahkamah Konstitusi sebagai satu-satunya lembaga yang diberikan otoritas untuk menafsirkan sebuah konstitusi, sehingga diharapkan peraturan perundang-undangan lainnya tidak menyalahi konstitusi. Selain itu mengingat bahwa sistem hukum RI yang civil law maka negara harus berdasarkan pada prinsip-prinsip konstitusi. Adapun negara 
berdasarkan prinsip-prinsip konstitusi mengandung makna antara lain; pertama, adanya pengaturan mengenai batas-batas peran negara atau pemerintahan dalam mencampuri kehidupan dan pergaulan masyarakat, dan kedua, adanya jaminan hukum akan hak-hak, baik sipil (individual rights), hak-hak politis (political rights), maupun hakhak sebagai sebuah kelompok atau hak-hak sosialsebagai hak asasi yang melekat secara alamiah pada setiap insan baik secara pribadi atau

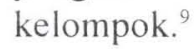

Selanjutnya pengaturan tentang Mahkamah Konstitusi secara khusus terdapat dalam Pasal 24 C Undang-Undang Dasar Negara Republik Indonesia yakni:

a. Mahkamah Konsititusi berwenang mengadili pada tingkat pertama dan terakhir yang putusannya bersifat final untuk menguji undang-undang terhadap Undang-Undang Dasar, memutus sengketa kewenangan lembaga negara yang kewenangannya diberikan oleh Undang-Undang Dasar, memutus pembubaran partai politik, dan memutus perselisihan tentang hasil pemilihan umum.

b. Mahkamah Konstitusi wajib memberikan putusan atas pendapat Dewan Perwakilan Rakyat mengenai dugaan pelanggaran oleh Presiden dan/atau Wakil Presiden menurut Undang-Undang Dasar.

c. Mahkamah Konstitusi mempunyai sembilan orang anggota hakim konstitusi yang ditetapkan oleh Presiden, yang diajukan masing-masing tiga orang oleh Mahkamah Agung, tiga orang oleh Dewan Perwakilan Rakyat, dan tiga orang oleh Presiden.

d. Hakim konstitusi harus memiliki integritas dan kepribadian yang tidak tercela, adil, negarawan yang menguasai konstitusi dan ketatanegaraan, serta tidak merangkap sebagai pejabat negara.

e. Pengangkatan dan pemberhentian hakim konstitusi, hukum acara serta ketentuan lainnya tentang Mahkamah Konstitusi diatur dengan undang-undang.

${ }^{9}$ Abdul Latif, "Fungsi Mahkamah Konstitusi dalam Mewujudkan Negara Hukum Demokrasi”, (Yogyakarta: Total Media, 2009), hal. 99. 


\section{Analisis Pembatasan Pembubaran Partai Politik}

Isu hukum mengenai pembubaran partai politik dewasa ini masih menimbulkan polemik karena keberadaan partai politik di negara yang bersistem politik demokrasi, dianggap merupakan "condition sine quanon". Meskipun demikian secara yuridis suatu partai politik dapat dibubarkan jika ideologinya bertentangan dengan ideologi negara dan melanggar hukum.

Secara normatif pelaksanaan pembubaran partai politik menjadi kewenangan Mahkamah Konsitusi sebagaimana diatur dalam Pasal 24C ayat (1) UUD 1945 yakni "Mahkamah Konstitusi mengadili pada tingkat pertama dan terakhir yang putusannya bersifat final untuk ....memutus pembubaran partai politik..." Selanjutnya pembubaran suatu partai politik oleh Mahkamah Konstitusi hanya dapat dilakukan apabila didasarkan pada alasanalasan yuridis yakni melanggar larangan-larangan seperti salah satunya yang ditegaskan dalam Pasal 40 Undang-Undang Nomor 2 Tahun 2008 Tentang Partai Politik.

Menurut Pasal 40 ayat (1) disebutkan bahwa Partai Politik dilarang menggunakan nama, lambang atau tanda gambar yang sama dengan:

a. Bendera atau lambang negara Republik Indonesia;

b. Lambang lembaga negara atau lambang pemerintah;

c. Nama. Bendera, lambang negara lain atau lembaga/badan internasional;

d. Nama, bendera, simbol organisasi gerakan separatis atau organisasi terlarang;

e. Nama atau gambar seseorang; atau

f. Yang mempunyai persamaan pada pokoknya atau keseluruhannya dengan nama, lambang, atau tanda gambar Partai Politik lain.

Selanjutnya pada ayat (2) disebutkan bahwa Partai Politik dilarang:

a. Melakukan kegiatan yang bertentangan dengan Undang-Undang Dasar Negara Republik Indonesia Tahun 1945 dan peraturan perundang-undangan;

b. Melakukan kegiatan yang membahayakan keutuhan dan keselamtan Negara Kesatuan Republik Indonesia.

Kemudian pada Pasal 40 ayat (3), ditegaskan pula adanya larangan bagi Partai Politik:

a. Menerima dan/atau memberikan kepada pihak asing sumbangan dalam bentuk apapun yang bertentangan dengan peraturan perundang-undangan; 
b. Menerima sumbangan berupa uang berupa uang, barang, ataupun jasa dari pihak manapun tanpa mencatumkan identitas yang jelas;

c. Menerima sumbangan dari perseorangan dan/atau perusahaan/badan usaha melebihi batas yang ditetapkan dalam peraturan perundangundangan;

d. Meminta atau menerima dana dari badan usaha milik negara, badan usaha milik daerah dan badan usaha milik desa atau dengan sebutan lainnya; atau

e. Menggunakan fraksi di Majelis Permusyaratan Rakyat, Dewan Perwakilan Rakyat, Dewan Perwakilan Rakyat Daerah Provinsi, dan Dewan Perwakilan Rakyat Daerah Kabupaten/Kota sebagai sumber pendanaan Partai Politik.

Sebagai penutup pada ayat (4) ditegaskan juga Partai Politik dilarang mendirikan badan usaha dan/atau memiliki saham suatu badan usaha. Dan pada ayat (5) Partai Politik dilarang menganut dan mengembangkan serta menyebarkan ajaran atau paham komunisme/Marxisme Leninisme.

Berkaitan dengan partai politik yang melanggar hukum sebagai misalnya menerima suap atau sumbangan dana yang melebihi batas maksimum yang dibolehkan oleh peraturan perundang-undangan, dan tidak mencantumkan identitas pemberi sumbangan dana, perlu terlebih dahulu Mahkamah Konstitusi mengadakan pengujian terhadap bukti-bukti keterlibatan partai politik yang bersangkutan yang diduga menerima suap atau sumbangan dana tersebut. Apabila diketemukan bukti-bukti yang kuat bahwa partai politik melanggar hukum, selanjutnya ditelusuri pengaturan hukumnya yakni pada ketentuan pasal-pasal manakah yang dilanggar partai politik.

Berkaitan dengan ketentuan pasal-pasal yang dilanggar sudah barang tentu yang ada relevansinya, yakni Pasal 40 ayat (3) huruf b, dan c UndangUndang Nomor 2 Tahun 2008 Tentang Partai Politik. Berdasarkan ketentuan tersebut menjadi pijkan bagi Mahkamah Konstitusi untuk membubarkan partai politik. Kewenangan pembubaran partai politik tidak hanya berlandaskan konstitusi tetapi juga diperkuat oleh Undang-Undang Nomor 2 Tahun 2008, yakni Pasal 41 huruf C yang menyebutkan bahwa Partai Politik bubar apabila dibubarkan oleh Mahkamah Konstitusi.

Meskipun telah diuraikan secara normatif pelaksanaan fungsi Mahkamah Konstitusi berkenaan dengan kewenangannya memutus pembubaran partai politik, namun masih menimbulkan kekaburan hukum (obscuur) sehubungan dengan adanya batasan-batasan yuridis yakni:

A. Hal ini terkait dengan pengaduan masyarakat terhadap partai politik yang melanggar hukum. 
Dalam hal ini masyarakat tidak dapat mengajukan permohonan kepada Mahkamah Konstitusi untuk membubarkan partai politik yang melanggar hukum. Hal ini sebagai akibat pembatasan UndangUndang Nomor 23 Tahun 2003 Tentang Mahkamah Konstitusi. Pada Pasal 68 ayat (1) disebutkan bahwa pihak yang dapat memohonkan pembubaran partai politik adalah Pemerintah.

Ketentuan Pasal 68 ayat (1) limitatif sifatnya sehingga tidak membuka kesempatan kepada masyarakat untuk mengajukan gugatan terhadap partai politik yang melanggar hukum. Keadaan ini semakin sulit apabila partai politik yang melanggar hukum adalah partai politik pemerintah. Dalam hal ini apakah pemerintah mau mengajukan permohonan kepada Mahkamah Konstitusi untuk memeriksa dan membubarkan parpolnya yang terbukti melanggar hukum.

Sebagai perbandingan di Korea Selatan pembubaran atau pembekuan kegiatan partai politik dapat diajukan oleh eksekutif jika partai politik tersebut dalam aktivitasnya telah bertentangan dengan dasar demokrasi, hak asasi, dan negara hukum setelah terlebih dahulu diperiksa oleh dewan negara, kemudian dewan mengajukan pembubaran atau pembekuan itu ke Mahkamah Konstitusi. Jika Mahkamah Konstitusi membubarkan atau membekukan partai politik tersebut, eksekusinya dilakukan olah KPU dan diumumkan oleh Mahkamah Konstitusi.

Di Jerman, pembubaran partai politik diajukan oleh Bundestag, Bundesrat, Pemerintah Federal, dan Pemerintah Negara Bagian, jika partai politik itu berada di wilayahnya. Bentuk putusan hakim konstitusi hanya berupa deklaratoir, artinya apakah partai politik konstitusional atau tidak dan putusan hakim tersebut hanya terbatas pada sisi hukum dan organisasi dari partai politik tersebut. Jika partai politik dinyatakan bubar, harta benda (bergerak dan tidak bergerak) disita menjadi milik negara.

Pada hakekatnya tidak diberikannya hak mengajukan gugatan atau permohonan terhadap pembubaran suatu partai politik tertentu oleh lembaga lain, misalnya partai politik lain yang merasa dirugikan atau masyarakat, misalnya LSM, menurut Abdul Rasyid Thalib, karena tidak menutup kemungkinan akan terjadi sengketa antar partai politik yang mengarah pada pencemaran nama baik dan perbuatan tidak menyenangkan yang bisa menimbulkan sengketa perdata atau tindak pidana. Sedangkan masyarakat atau lembaga lain tidak diberi hak untuk mengajukan permohonan pembubaran partai politik karena masyarakat tidak begitu jelas identitasnya dan tidak bisa mewakili 
masyarakat secara keseluruhan, tetapi lebih bersifat politis serta akan sulit melakukan pembuktian. ${ }^{10}$

Namun demikian adanya pembatasan yuridis kepada para pihak untuk mengajukan permohonan gugatan terhadap partai politik sebenarnya berlebihan karena membatasi ruang lingkup masyarakat untuk mengontrol tindakan partai politik. Hal ini melanggar prinsip demokrasi, dimana partai politik merupakan penopang berjalannya aspirasi politik masyarakat dalam suatu negara. Pentingnya masyarakat dilibatkan untuk mengontrol perilaku partai politik melalui proses permohonan ke Mahkamah Konstitusi karena dalam praktik ketatanegaraan dapat saja masyarakat memiliki bukti-bukti yang cukup kuat terhadap suatu partai politik termasuk partai politik pemerintah melakukan pelanggaran hukum secara keperdataan atau tindak pidana.

Sebagai misalnya dalam kasus keperdataan Partai A yang menanamkan modal dalam bentuk saham sejumlah Rp. 3 miliar ke PT B di Jakarta. Kemudian dalam perjalanannya PT. B dinyatakan pailit. Ternyata diketemukan bukti oleh masyarakat di PT.B terdapat saham Partai A sebesar Rp.3 miliar. Menurut Pasal 4 ayat (4) Undang-Undang Nomor 2 Tahun 2008 Tentang Partai Politik ditegaskan Partai Politik dilarang mendirikan badan usaha dan/atau memiliki saham suatu badan usaha. Hal ini artinya partai politik merupakan organisasi nirlaba dan dilarang mendirikan badan usaha dan/atau memiliki saham suatu badan usaha. Partai A bukan merupakan organisasi nirlaba karena itu dilarang mendirikan badan usaha atau menanamkan saham untuk badan usaha tertentu. kenyataan bahwa Partai A mengakui telah menanamkan saham pada PT. B atas persetujuan Dewan Pimpinan Pusat (DPP) Partai A.

Berdasarkan temuan tersebut seharusnya dalam Undang-Undang Nomor 2 Tahun 2008 memberikan kewenangan kepada masyarakat untuk mengajukan permohonan gugatan untuk pembubaran suatu partai politik. Untuk itu langkah yang perlu dilakukan adalah merevisi Pasal 68 ayat (1) yang dinilai tidak demokratis dan menghambat masyarakat untuk menggugat partai politik yang dinilai melanggar hukum. ${ }^{11}$

${ }^{10}$ Abdul Rasyid Thalib, "Wewenang Mahkamah Konstitusi dan Implikasinya dalam Sistem Ketatanegaraan Republik Indonesia", ( Bandung: Citra Aditya Bakti, 2006), hlm.432433.

11 Josef M.Monteiro, Opini tentang Pembubaran Parpol Skandal Bank Century Harian Umum Timor Express, Kupang, NTT, 3 Desember 2010. 


\section{B. Penafsiran Pasal 68 ayat (2).}

Pada ayat (2) ditegaskan bahwa pemohon wajib menguraikan dengan jelas dalam permohonannya tentang ideologi, asas, tujuan, program, dan kegiatan partai politik yang bersangkutan, yang dianggap bertentangan dengan Undang-Undang Dasar Negara Republik Indonesia Tahun 1945.

Hal ini mengandung arti bahwa untuk dapat membubarkan partai politik harus ada alasan politis yakni apabila ideologi, asas, tujuan, program, dan kegiatan partai politik dinilai bertentangan dengan Undang-Undang Dasar Negara Republik Indonesia Tahun 1945. Padahal pelanggaran hukum yang dilakukan oleh suatu partai politik pada dasarnya tidak hanya karena semata-mata bertentangan dengan konstitusi. Akan tetapi pelanggaran hukum itu dapat juga terjadi karena menyalahi peraturan perundang-undangan, yang dalam hal ini undang-undang, seperti Undang-Undang Nomor 2 Tahun 2008, yang berkenaan dengan penerimaan suap atau sumbangan dana yang melebihi batas maksimum dan tanpa mencatumkan identitas pemberi dana, dan sebagianya.

Perlu dipahami pula, istilah "undang-undang" yang dimaksud tidak saja dalam artian sempit sebagai undang-undang dalam arti formal seperti yang dimaksudkan dalam Pasal 5 dan Pasal 20 UndangUndang Dasar Negara Republik Indonesia Tahun 1945. Akan tetapi undang-undang dalam arti materiil yang di dalamnya menyangkut semua ketentuan undang baik yang sifatnya umum (lex generalis) maupun yang sifatnya khusus (lex specialis) yang mencantumkan adanya ancaman sanksi baik pidana maupun perdata.

Oleh karena itu semestinya pada rumusan kalimat Pasal 68 ayat (2) diberikan penafsiran secara ekstensif ${ }^{12}$, artinya pelanggaran hukum yang dilakukan oleh partai politik meliputi pelanggaran hukum yakni Undang-Undang Dasar Negara Republik Indonesia Tahun 1945, dan undang-undang (dalam arti formal maupun materiil). Dengan demikian makna ketentuan Pasal 68 ayat (2) adalah untuk dapat membubarkan partai politik, pemohon wajib menguraikan dengan jelas dalam permohonannya tentang ideologi, asas, tujuan, program, dan kegiatan partai politik yang bersangkutan, yang dianggap selain bertentangan dengan Undang-Undang Dasar Negara Republik Indonesia dan Undang-Undang.

${ }^{12}$ Interpretasi ekstensif adalah interpretasi yang sifatnya memperluas makna suatu ketentuan pasal. 
Berdasarkan hal tersebut maka perlu penyempurnaan terhadap ketentuan Pasal 68 ayat (1) dan (2) Undang-Undang-Undang Nomor 24 Tahun 2003 Tentang Mahkamah Konstitusi agar permohonan masyarakat dalam menggugat partai politik yang melanggar hukum dapat diakomodir dan mempunyai justifikasi, dalam rangka mewujudkan amanat Pasal 27 ayat (1) Undang-Undang Dasar Negara Republik Indonesia Tahun 1945 yang menyebutkan bahwa setiap warga negara memiliki kedudukan yang sama di depan hukum dan hal ini sebagai pencerminan prinsip equality before the law. Adapun prinsip ini mengandung pengertian bahwa tidak ada seorang pun atau pihak mana pun yang kebal hukum, sehingga jikalau seseorang atau sesuatu pihak melanggar hukum maka harus dikenai sanksi hukum.

\section{Penutup}

Partai politik merupakan salah satu pilar dalam sistem politik yang demokratis sehingga keberadaan partai politik dijadikan sarana untuk menghimpun ekspresi, ide, pikiran, pandangan, dan keyakinan masyarakat serta dijadikan juga sarana untuk meraih kekuasaan terutama jabatan legislatif dan eksekutif.

Oleh karena itu pembubaran partai politik masih menimbulkan polemik karena keberadaan partai politik di negara yang bersistem politik demokrasi, dianggap merupakan "condition sine quanon". Meskipun demikian secara yuridis suatu partai politik dapat dibubarkan jika ideologinya bertentangan dengan ideologi negara dan melanggar hukum. Pembubaran partai politik oleh Mahkamah Konstitusi hanya dapat dilakukan apabila didasarkan pada alasan-alasan yuridis yakni melanggar laranganlarangan seperti yang ditegaskan dalam Pasal 40 Undang-Undang Nomor 2 Tahun 2008 Tentang Partai Politik.

Namun dalam pelaksanaan fungsi Mahkamah Konstitusi memutuskan pembubaran partai politik, masih terdapat pembatasan-pembatasan yuridis yang berimplikasi terhadap prinsip demokrasi. Adapun pembatasanpembatasan yuridis yang dimaksud terkait ketentuan Pasal 68 ayat (1) dan (2) Undang-Undang-Undang Nomor 24 Tahun 2003 Tentang Mahkamah Konstitusi, yang dinilai menimbulkan kekaburan hukum (obscuur). Untuk itu langkah yang perlu dilakukan adalah merevisi Pasal 68 ayat (1) yang dinilai tidak demokratis dan menghambat masyarakat untuk menggugat partai politik yang dinilai melanggar hukum. Pembatasan terhadap ruang lingkup masyarakat untuk mengontrol tindakan partai politik melanggar prinsip demokrasi, dimana partai politik merupakan penopang berjalannya aspirasi politik masyarakat dalam suatu negara. Pentingnya masyarakat dilibatkan 
untuk mengontrol perilaku partai politik melalui proses permohonan ke Mahkamah Konstitusi karena dalam praktik ketatanegaraan dapat saja masyarakat memiliki bukti-bukti yang cukup kuat terhadap suatu partai politik termasuk partai politik pemerintah melakukan pelanggaran hukum secara keperdataan atau tindak pidana.

Kemudian rumusan kalimat Pasal 68 ayat (2) diberikan penafsiran secara ekstensif yakni untuk dapat membubarkan partai politik, pemohon wajib menguraikan dengan jelas dalam permohonannya tentang ideologi, asas, tujuan, program, dan kegiatan partai politik yang bersangkutan, yang dianggap selain bertentangan dengan Undang-Undang Dasar Negara Republik Indonesia dan Undang-Undang. Adapun undang-undang dalam arti materiil yang di dalamnya menyangkut semua ketentuan undang baik yang sifatnya umum (lex generalis) maupun yang sifatnya khusus (lex specialis), yang mencantumkan adanya ancaman sanksi baik pidana maupun perdata. 


\section{Daftar Pustaka}

Abdul Rasyid Thalib, Wewenang Mahkamah Konstitusi dan Implikasinya dalam Sistem Ketatanegaraan Republik Indonesia, Bandung: Citra Aditya Bakti, 2006.

Abdul Latif, Fungsi Mahkamah Konstitusi dalam Mewujudkan Negara Hukum Demokrasi, Yogyakarta: Total Media, 2009.

Appadorai, A, The Substance of Politics, New Delhi: Oxford University Press, 2005.

Asshiddiqie, Jimly, Pokok-Pokok Hukum Tata Negara Indonesia, Jakarta: Bhuana Ilmu Populer, 2007.

Budiardjo, Miriam, Dasar-Dasar Ilmu Politik, Jakarta: Gramedia, 1977. , Partisipasi dan Partai Politik: Sebuah Bunga Rampai, 1982 Jakarta: Gramedia.

Liddle, William, R, Pemilu-Pemilu Orde Baru: Pasang Surut Kekuasaan Politik, Jakarta: LP3ES, 1994.

Monteiro, J, Josef, "Pembubaran Parpol Skandal Bank Century", Opini Harian Umum Timor Express, Kupang, NTT, 3 Desember 2010.

Undang-Undang Dasar Negara Republik Indonesia Tahun 1945.

Undang-Undang Nomor 24 Tahun 2003 Tentang Mahkamah Konstitusi, Lembaran Negara RI Nomor 4316.

Undang-Undang Nomor 2 Tahun 2008 Tentang Partai Politik, Lembaran Negara RI Nomor 4251. 